\title{
Influence of processing on the fatty acid composition and the content of conjugated linoleic acid in organic and conventional dairy products - a review
}

\author{
Walter BISIGa,b*, Pius EBERHARDa ${ }^{a}$, Marius COLLOMBa, \\ Brita REHBERGER ${ }^{a}$ \\ a Agroscope Liebefeld-Posieux Swiss Federal Research Station for Animal Production and Dairy \\ Products (ALP), Schwarzenburgstr. 161, 3003 Bern, Switzerland \\ b University of Applied Sciences Berne, Swiss College of Agriculture, Länggasse 85, \\ 3052 Zollikofen, Switzerland
}

Received 11 July 2006 - Accepted 10 January 2007

\begin{abstract}
An overview of the present knowledge on the influences of dairy processing and storage on the content of conjugated linoleic acids (CLA) and to possible differences between organic and standard products is given. In organic dairy products CLA was reported to be from not significantly up to $135 \%$ higher. Newer studies on the effect of heating steps show no changes in CLA content or isomer profiles, with the exception of microwaving, where CLA was decreased by up to 53\%. In commercial dairy products no effects of fermentation on CLA content were observed. Recent studies on cheese showed no changes in the CLA content during manufacturing or ripening. CLA content was stable during butter-making out of CLA-enriched milk. In several more recent investigations with probiotic bacteria (lactic acid bacteria such as Lactobacillus rhamnosus or Lactobacillus acidophilus, and propionibacteria and bifidobacteria such as B. breve and B. dentium) or other strains of these bacteria groups on a laboratory scale, an increase in CLA could be observed under the condition that free linoleic acid (LA) was available in the culture medium. Conversion rates reached up to $87 \%$ with Propionibacteria freudenreichii ssp. shermanii. In cultivated form, B. breve reached a comparably high concentration of $398 \mathrm{mg} C L A \cdot L^{-1}$ broth. Especially high concentrations of up to $40 \mathrm{~g} \mathrm{CLA} \cdot \mathrm{L}^{-1}$ broth could be produced with resting cells of Lactobacillus plantarum and Lb. acidophilus or with immobilised cells of Lb. delbrueckii ssp. bulgaricus. CLA formation in yoghurt could be observed under the condition that free LA was added. After 14 days of storage the increase was $77 \%$. Specific procedures allow one to increase the content of CLA in a fraction. These procedures are dry fractionation (63\% increase), fractionation using supercritical carbon dioxide ( $89 \%$ increase) and crystallisation (concentration 2.5 times). Numerous studies on the shelf-life stability of CLA-enriched dairy products showed no significant differences in flavour quality parameters.
\end{abstract}

conjugated linoleic acid / dairy product / processing / shelf-life stability / organic product

\footnotetext{
* Corresponding author (通讯作者): walter.bisig@alp.admin.ch
} 
概要 - 加工过程对有机和普通乳制品中脂肪酸组成和共轭亚油酸含量的影响一文献综述。 本文综述了加工和败藏过程对有机和普通乳制品中共轭亚油酸 (CLA) 的影响以及探讨了有 机乳制品与普通乳制品之间可能存在的差异。有机乳制品之间 CLA 含量没有显著性的差 异，但是高于普通乳制品 CLA 含量平均值的 $135 \%$ 。最新的研究结果表明热处理不能改变 CLA的含量或者异构体分布性质，但微波处理使得CLA损失量达到 $53 \%$ 。在大量生产的乳制 品中，发酵对 CLA 的含量没有影响，干酪的制造和成熟过程对干酪中 CLA 含量也没有影 响。从富含 CLA 的牛奶制造奶油, CLA 含量在乳脂肪中保持不变。许多最新的研究结果 表明在实验室规模下培养益生菌 (乳酸菌如鼠李糖乳杆菌、嗜酸乳杆菌, 丙酸菌, 双歧杆 菌如短双岐杆菌和齿双歧杆菌) 或其他微生物菌株能够将亚油酸 (LA) 转化为 CLA。 Propionibacteria freudenreichii ssp. shermanii 将 LA 转化为 CLA 的转化率达到 $87 \%$ 。在 B. breve 培养基中 CLA 的含量高达 $398 \mathrm{mg} \mathrm{CLA} \cdot \mathrm{L}^{-1}$ (培养液)。特别是在 Lactobacillus plantarum 和 Lb. acidophilus 的休眠细胞或者Lb. delbrueckii ssp. bulgaricus的固定化细胞中CLA的含量高达 到 $40 \mathrm{~g} \mathrm{CLA} \cdot \mathrm{L}^{-1}$ (培养液)。在酸奶中加入游离的亚油酸可以检测到生成的 CLA, 酸奶只藏 $14 \mathrm{~d}$ 后, CLA 的含量增加了 77\%。采用特殊的分离方法可以增加馏分中CLA的含量, 干法分 提可以使 CLA 的含量增加 63\%，二氧化碳超临界流体萃取技术使 CLA 的含量增加 89\%， 而结晶法则可以使 CLA 浓缩 2.5 倍。大量实验证明富含 CLA 的乳制品的在货架期内 CLA 稳定并且乳制品的风味和质量参数没有显著的变化。

共轭亚油酸 / 乳制品 / 加工 / 货架稳定性 / 有机的

Résumé - Influence de la fabrication sur la composition des acides gras et la concentration en acides linoléiques conjugués dans des produits laitiers biologiques et standards. La présente étude donne une vue d'ensemble des connaissances concernant l'influence de la fabrication et du stockage des produits laitiers sur la concentration en acides linoléiques conjugués (CLA) et les différences possibles entre les produits biologiques et les produits standards. Dans les produits laitiers bio, il est reporté que la concentration en CLA est plus élevée dans des proportions allant de non significatif à $135 \%$. Il ressort de nouvelles études conduites sur l'effet du chauffage que celui-ci n'entraîne aucune modification au niveau de la concentration en CLA ou de la répartition des isomères, à l'exception du chauffage par micro-onde avec lequel la concentration en CLA pouvait être inférieure de $53 \%$. De même, aucun effet de la fermentation sur la concentration en CLA dans les produits laitiers du commerce n'a été observé. Des études récentes sur le fromage n'ont montré aucune modification de la concentration en CLA pendant la fabrication ou la maturation. La concentration en CLA est restée stable pendant la fabrication de beurre à base de lait enrichi en CLA. Dans plusieurs études plus récentes effectuées à l'échelle du laboratoire avec des bactéries probiotiques (bactéries lactiques comme Lactobacillus rhamnosus ou Lactobacillus acidophilus, bactéries propioniques et bifidobactéries comme $B$. breve et $B$. dentium) ou d'autres souches de ces groupes de bactéries, il a été observé une augmentation de la concentration en CLA en présence d'acide linoléique libre (LA) dans le milieu de culture. Les taux de conversion ont atteint jusqu'à $87 \%$ avec Propionibacteria freudenreichii ssp. shermanii. Sous forme cultivée, B. breve a atteint une concentration comparativement élevée de $398 \mathrm{mg} C L A \cdot \mathrm{L}^{-1}$ de milieu de culture. Des concentrations particulièrement élevées allant jusqu'à $40 \mathrm{~g}$ CLA $\cdot \mathrm{L}^{-1}$ de milieu de culture ont pu être produites avec des cellules de Lactobacillus plantarum et de Lb. acidophilus qui ne sont plus actives ou avec des cellules immobilisées de $\mathbf{L b}$. delbrueckii ssp. bulgaricus. Par ailleurs, la formation de CLA dans le yoghourt a été observée dans la mesure où l'on y ajoutait du LA libre. En effet, après 14 jours d'entreposage, l'augmentation était de $77 \%$. Des procédés spécifiques permettent d'augmenter la concentration de CLA dans une fraction ; il s'agit entre autres du fractionnement à sec $(63 \%$ d'augmentation), du fractionnement au dioxyde de carbone supercritique (89\% d'augmentation) et de la cristallisation (concentration : 2,5 fois). De nombreuses études sur la stabilité pendant l'entreposage des produits laitiers enrichis avec des CLA ne montrent aucune différence significative au niveau des paramètres sensoriels de qualité.

acide linoléique conjugué / produit laitier / transformation / stabilité pendant l'entreposage / produit biologique 


\section{INTRODUCTION}

Conjugated linoleic acid isomers (CLA) have been of much interest since their anticarcinogenic activity was discovered two decades ago by $[25,59]$. The proposed daily intake of CLA to provide anticarcinogenic response in humans ranges from $55 \mathrm{mg}$ above basal CLA intake to 3.0 to $3.5 \mathrm{~g} \cdot \mathrm{d}^{-1}$. The first value is based on diet and cancer risk studies and the second on the amount of CLA required for an anticarcinogenic response extrapolated from rats to humans [7]. Many other biological activities such as anti-atherogenic, anti-adipogenic, anti-diabetogenic, antiinflammatory and beneficial regulatory effects on immune function were found [60, 61, 81]. Collomb et al. [13] give a review of the physiological effects of CLA. In human studies often not the same effects suggested based on animal studies are found. The CLA content in dairy products was 0.338 to $0.796 \mathrm{~g} \cdot 100 \mathrm{~g}^{-1}$ lipid in a survey of 22 different dairy products and cheeses from a supermarket in Pullmann, Washington [41]. Collomb et al. [11] found in a study of 44 milk samples from three different regions in Switzerland (lowlands, mountains and highlands) CLA concentrations of $0.87,1.61$ and $2.36 \mathrm{~g} \cdot 100 \mathrm{~g}^{-1}$ lipid, respectively. It was found that the CLA content in milk is influenced by the cows' $\operatorname{diet}[11,12,40,62,66]$. Ledoux et al. [38] found important differences in CLA content between summer and winter butter (0.80 and $0.45 \mathrm{~g}$ CLA $100 \mathrm{~g}^{-1}$ butter, respectively). The same authors and Collomb et al. [11] showed that milk from mountainous areas had a higher CLA content than milk from lower regions. In deviation to these findings butter from the prairie land in Normandy showed similar values to butter from mountainous areas. Couvreur et al. [14] found a linear positive relationship between the proportion of fresh grass in the cows' diet and the concentration of unsaturated fatty acids, as well as the concentration of CLA, with +0.38 and $+0.12 \%$, respectively, per $+10 \%$ of fresh grass. In their recent review on the variation of CLA in unprocessed milk fat, Collomb et al. [13] report values ranging from 0.2 to $5.37 \mathrm{~g} \cdot 100 \mathrm{~g}^{-1}$ fat. The highest reported value was from a study of Shingfield et al. [76] obtained by a diet supplemented with fish oil and sunflower oil. In many studies the influence of microorganisms on CLA content in culture media and dairy products was investigated. Sieber et al. [77] reviewed these studies. Strains of lactobacilli, bifidobacteria and propionibacteria were found to be able to convert linoleic acid efficiently into CLA in culture media. However, several investigations on yoghurt and cheese did not show elevated CLA levels. In the meantime, many more studies in this field were published. There is information that processing, such as heating, can change the CLA isomer distribution in dairy products while the total CLA content is unchanged by conventional processing [79]. This review aims to give an overview of the current knowledge about the influences of dairy processing and storage on the fatty acid composition, and especially the content of conjugated linoleic acid isomers. Special attention is given to differences in products of organic origin compared with products originating in conventional and integrated farming.

\section{CLA AND OTHER COMPOUNDS IN ORGANIC PRODUCTS}

Jahreis et al. [28] compared the composition of fatty acids in three types of bulk milk from conventional farming with indoor feeding, conventional farming with grazing during summer and organic farming. The milk from organic farming showed the highest content of CLA, $0.80 \%$ of the total fatty acid methyl esters (FAME) in comparison with $0.34 \%$ and $0.61 \%$ for the conventional-indoor and the conventionalwith-grazing groups. Also, for transvaccenic acid, similar influences were found. Bergamo et al. [6] investigated 3 organic buffalo milks and corresponding Mozzarella cheeses, 8 conventional milks and corresponding Mozzarella cheeses of southern Italian origin and 4 different brands ( 2 organic, 2 conventional) of cow's milk and cow's milk products: pasteurised milk, UHT milk, Parmigiano cheese, 
Mozzarella cheese, butter, Ricotta cheese, Crescenza cheese and Fontina cheese of Italian or European origin. Their findings confirmed the main results of Jahreis et al. [28]. In organic buffalo milk and Mozzarella cheese the CLA concentration was 0.73$0.90 \mathrm{~g} \cdot 100 \mathrm{~g}^{-1}$ fat, while conventional buffalo milk and Mozzarella cheese showed CLA contents of $0.55-0.62 \mathrm{~g} \cdot 100 \mathrm{~g}^{-1}$ fat. In organic cow's milk, cheese and dairy products, $0.58-1.18 \mathrm{~g}$ CLA $100 \mathrm{~g}^{-1}$ fat were found with a content in Crescenza cheese and Fontina cheese of 1.18 and $1.03 \mathrm{~g} \cdot 100 \mathrm{~g}^{-1}$ fat, respectively. Conventional cow's milk, cheese and dairy products had CLA contents of $0.50-0.62 \mathrm{~g} \cdot 100 \mathrm{~g}^{-1}$ fat. CLA was around $50 \%$ higher in organic products compared with conventional ones. Also, higher contents of linolenic acid $(+\approx 50 \%)$, trans-11 C18:1 (trans-vaccenic acid, TVA) $(+\approx 50 \%), \quad \beta$-carotene $(+76 \%)$ and $\alpha-$ tocopherol $(+\approx 50 \%)$ were found in organic products compared with the conventional ones. Linoleic acid (LA) was $31 \%$ lower in organic products. The CLA/ LA ratio was found to be $131 \%$ higher in organic milk fat compared with conventional milk fat and it is proposed as a marker for the identification of organic dairy products. The higher levels of the antioxidants $\alpha$-tocopherol and $\beta$-carotene in organic milk fat has positive implications on the stability of the organic milk fat and also on human nutrition [6]. The study of Ellis et al. [18], on the contrary, found no significantly higher contents of CLA and TVA in bulk milk from 17 organic farms compared with the milk of 19 conventional farms in the United Kingdom. However, they found a higher proportion of polyunsaturated fatty acids to monounsaturated fatty acids and of n-3 fatty acids than in conventional milk. According to Jahreis et al. [28] and Bergamo et al. [6], a reason for the higher CLA content in organic milk is the fact that there are more polyunsaturated fatty acids in the diet of cows with the organic system compared with conventional farming systems. This allows the possibility of CLA formation through biohydrogenation by rumen bacteria. Another reason could be the fibre-rich diet in organic farming systems which might influence biohydrogenation, yielding higher concentrations of CLA.

\section{INFLUENCE OF HEATING AND OTHER PROCESSING STEPS ON CLA CONTENT}

\subsection{Heating and processed cheese}

The effects of heating, processing conditions, storage, cooking or aging on the composition of milk fat in milk and dairy products have often been discussed controversially. Processed cheese is manufactured by blending shredded natural cheeses with emulsifying agents and then heating the blend under partial vacuum while agitating, until a homogeneous mass is formed. Ha et al. [26] and Garcia-Lopez et al. [21] reported increased levels of CLA in processed cheeses as compared with natural cheeses, and Shanta et al. [74, 75] showed that an increase in processing temperature and the addition of whey protein concentrate could increase CLA concentration during the preparation of processed cheese. The studies of van Nieuwenhove et al. [80] and Luna et al. [49] support that heating at a high temperature does not raise CLA levels in milk fat. Campbell et al. [8] and Precht et al. [64] observed losses of CLA through hightemperature-short-time pasteurisation or more severe heat treatment up to $200{ }^{\circ} \mathrm{C}$. A more recent study on processed cheese applying the processing temperature schemes $90^{\circ} \mathrm{C}$-instantaneous combined with $70^{\circ} \mathrm{C}$ $30 \mathrm{~min}$ or $139^{\circ} \mathrm{C}-2.4 \mathrm{~s}$ combined with $85^{\circ} \mathrm{C}-45$ min could not detect significant changes in CLA levels throughout the production process and did not modify the isomer profile. Accurate analytical methods combining $\mathrm{Ag}^{+}-\mathrm{HPLC}$ columns in series with GC-MS were used [50]. Herzallah et al. [27] conclude, based on their study on milk, yoghurt, fresh cheese and white brined ewe's milk cheese, with the exception of microwaving, that none of the heat treatments used caused significant changes in CLA content. Microwaving caused a significant decrease in CLA content in milk and white brined cheese. The loss was up to $53 \%$. 


\subsection{Effects of the cheesemaking process}

Lin et al. [42] found a significantly higher CLA content in canned cheese in comparison with vacuum pouch-packed cheese $\left(0.303 \quad \mathrm{~g} \cdot 100 \quad \mathrm{~g}^{-1}\right.$ fat and $0.270 \mathrm{~g} \cdot 100 \mathrm{~g}^{-1}$ fat, respectively). They found other reducing influences of the cheesemaking process such as higher or lower milling $\mathrm{pH}$ compared with the standard $\mathrm{pH}$ of 5.7 and the addition of the antioxidant BHA (butylated hydroxyanisole) on the CLA content in Cheddar cheese. Lin et al. [43] measured the highest CLA content in Cheddar cheese after three months of ripening and concluded that the content of CLA in Cheddar-type cheeses might be controlled by the stage and conditions of processing. Gürsoy et al. [24] investigated 30 commercial Turkish hard and soft cheeses and detected the highest CLA content in hard cheeses with a long aging time. No further explanation is given. Also Ha et al. [26] and Prandini et al. [63] reported higher CLA contents in the fat of cheese than in the fat of milk. Werner et al. [82], Jiang et al. [29], Gnädig et al. [22], Nudda et al. [54] and Ryhänen et al. [73] observed no significant effect of processing on the CLA content in cheese, including blue cheese, Edam cheese, Swedish Swisstype cheese, French Emmental and other hard cheeses, and Pecorino Romano cheese and Ricotta cheese made from the corresponding sheep's milk. Gnädig et al. [22] investigated different processing factors such as raw or mildly heated milk $\left(68^{\circ} \mathrm{C} / 20 \mathrm{~s}\right)$, cooking/moulding temperatures of $52{ }^{\circ} \mathrm{C} / 50{ }^{\circ} \mathrm{C}$ or $48{ }^{\circ} \mathrm{C} / 48{ }^{\circ} \mathrm{C}$ or $50{ }^{\circ} \mathrm{C} /$ $50{ }^{\circ} \mathrm{C}$ and different strains of Propionibacterium freundenreichii, and found no effect on CLA content in French Emmental cheese.

\subsection{Effects of yoghurt and fermented milk processing}

In the production of yoghurt, production practices do not contribute to significant changes in CLA content [7, 16, 29, 75]. Boylston and Beitz [7] and Dave et al. [16] investigated the manufacturing of yoghurt made out of milks varying in their content of CLA and other fatty acids. There were no significant changes in CLA content or fatty acid distribution. The CLA content was also stable over a 7-d or 30-d storage period. Furthermore, changes in fatty acid composition as a result of change in the diet of the cows did not show any significant effects on the viable numbers of starter bacteria [16].

\subsection{Other manufacturing procedures}

Microbial fermentation, through isomerase and reductase reactions of the biohydrogenation pathway, contributed to increases in CLA during the production of ghee [4]. Ryhänen et al. [73] increased CLA content in milk by feeding cows a diet with $0.5 \mathrm{~kg}$ rapeseed oil per day, and manufactured butter out of this CLAenriched milk using a starter containing Lactococcus lactis and Leuconostoc mesenteroides. During the manufacture of the butter there were no changes in the concentrations of CLA in milk fat. The CLA content in butter was 0.9 to $1.1 \%$ of fatty acids. In their review about the influence of milk homogenisation on human health Michalski and Januel [52] mention no influence on CLA or fatty acid composition. There is probably no direct influence of this process step on the fatty acid composition of milk fat.

\section{INFLUENCE OF DAIRY STARTER CULTURES}

The interest in the possible ability of dairy starter cultures to increase the CLA content in dairy products is vast. As a significant proportion of the CLA isomers are formed during biohydrogenation of linoleic acid in the rumen by the bacterium Butyrivibrio fibrisolvens, it was to be expected that bacteria used as dairy starter cultures would also have the ability to form CLA. Many studies have been published in this research area. Most of them investigate selected bacterial strains under controlled conditions in laboratory media or model systems. Selected strains of lactobacilli, bifidobacteria and propionibacteria were 
found to convert added linoleic acid efficiently into CLA. Sieber et al. [77] extensively reviewed the work published in this field until 2003. In this review mainly the more recent literature in this field will be summarised.

Jiang et al. [30] screened 19 different strains of lactobacilli, lactococci, streptococci and propionibacteria commonly used as dairy starter cultures for their ability to produce conjugated linoleic acid (CLA) from free linoleic acid in vitro. Two strains of Propionibacterium freudenreichii ssp. freudenreichii (ATCC 6207 and Propioni$6)$ and one strain of $P$. freudenreichii ssp. shermanii (9093) were found to be capable of converting free linoleic acid into extracellular CLA in MRS broth or skimmed milk. The highest level of CLA formed in the media was $265 \mu \mathrm{g} \cdot \mathrm{mL}^{-1}$ (Tab. I). Of the different isomers, cis- and trans-9,11-octadecadienoic acids represented 75 to $93 \%$ of the total CLA formed. In skimmed milk 60-90\% of linoleic acid was transferred into CLA. Kim and Liu [34] screened 13 lactic acid bacteria for CLA production in MRS media and in whole milk. Sunflower oil was added as a lipid source. In whole milk nine strains increased CLA content. Lactococcus lactis l-01 showed the highest CLA-converting ability both in MRS media and in whole milk. Up to $11 \mathrm{mg}$ CLA.g ${ }^{-1}$ fat was attained in comparison with $4.2 \mathrm{mg} \cdot \mathrm{g}^{-1}$ in the control.

\subsection{Propionibacteria}

Based on the findings that certain strains of propionibacteria $[30,65,71,77$ and others] or their enzyme extract [46] can transfer linoleic acid effectively into CLA with high conversion rates of up to $87 \%$, further investigations were carried out. Xu et al. [83] investigated 11 probiotic bacteria for the ability to form CLA. Three of them were propionibacteria. All 11 bacteria were able to form CLA when linoleic acid from hydrolysed soy oil as a substrate was present. With milk fat or unhydrolysed soy oil CLA increase could not be detected or was below $0.2 \mathrm{mg} \cdot \mathrm{g}^{-1}$ lipid. Propionibacterium freudenreichii ssp. shermanii 56, $P$. freudenreichii ssp. shermanii 51 and $P$. freudenreichii ssp. freudenreichii 23 demonstrated the greatest increase in CLA content. The highest CLA content was $1.65 \mathrm{mg} \cdot \mathrm{g}^{-1}$ lipid (Tab. I). Xu et al. [84] applied a selected strain of Lactobacillus rhamnosus and the same strains of Propionibacteria freudenreichii for the production of fermented milk. Their corresponding work is presented in Section 5.

\subsection{Bifidobacteria}

Coakley et al. [9] assessed strains of Lactobacillus, Lactococcus, Pediococcus and Bifidobacterium from different bacteria collections for their ability to produce CLA from free linoleic acid. The culture media was MRS broth and MRS broth with added cysteine hydrochloride. Nine strains of bifidobacteria produced the cis- 9 , trans- 11 CLA isomer from free linoleic acid. They found considerable interspecies variation in the ability for conversion. Different strains of $B$. breve and $B$. dentium were the most efficient CLA producers (Tab. I). B. breve $N C F B 2258$ converted $65 \%$ of the linoleic acid into CLA. Out of $0.55 \mathrm{mg} \cdot \mathrm{mL}^{-1}$ linoleic acid, this strain produced $0.36 \mathrm{mg} \cdot \mathrm{mL}^{-1} \quad$ CLA cis-9, trans- 11 . Lactobacilli, lactococci and pediococci did not produce detectable CLA. They suggest in accordance with Oh et al. [58] that CLA production by probiotic bifidobacteria could be a possible mechanism for their healthenhancing properties. Oh et al. [58] screened about 300 colonies of bifidobacteria strains isolated from breast-fed infants for the ability to produce CLA. Several colonies were found to produce reasonable amounts of CLA and two strains were selected because they had the highest CLAproducing ability. These were identified as $B$. breve and $B$. pseudocatenulatum. Five hundred $\mathrm{mg}$ linoleic acid $\cdot \mathrm{L}^{-1}$ was added as a substrate for the CLA conversion. The CLA concentrations reached 160 and $135 \mathrm{mg} \cdot \mathrm{L}^{-1}$, respectively. Total CLA conversion was $78 \%$ for $B$. breve and $69 \%$ for $B$. pseudocatenulatum from $0.01 \%$ linoleic acid. Rosberg-Cody et al. [70] tested bifidobacteria isolated from faecal material of 24 neonates for their ability to 
Table I. CLA production by microorganisms (adapted and updated from [57]).

\begin{tabular}{|c|c|c|c|c|c|c|c|c|}
\hline \multirow[t]{2}{*}{ Strain } & \multirow[t]{2}{*}{$\begin{array}{c}\text { Reaction } \\
\text { method }^{\mathrm{a}} \\
\text { /substrate }^{\mathrm{b}}\end{array}$} & \multicolumn{4}{|c|}{ CLA isomers } & \multirow[t]{2}{*}{$\begin{array}{l}\text { Productivity } \\
\left(\mathrm{mg} \cdot \mathrm{L}^{-1}\right)\end{array}$} & \multirow[t]{2}{*}{$\begin{array}{c}\text { Conversion } \\
\text { of LA into CLA }\end{array}$} & \multirow[t]{2}{*}{ Ref. } \\
\hline & & $\mathrm{c} 9, \mathrm{t} 11$ & $\mathrm{t} 9, \mathrm{t} 11$ & $\mathrm{t} 10, \mathrm{c} 12$ & Others & & & \\
\hline $\begin{array}{l}\text { Bifidobacterium } \\
\text { adolescentis }\end{array}$ & $\mathrm{c} / \mathrm{LA}$ & $46 \%$ & $20 \%$ & $34 \%$ & & 3.5 & & [9] \\
\hline $\begin{array}{l}\text { Bifidobacterium } \\
\text { angulatum }\end{array}$ & $\mathrm{c} / \mathrm{LA}$ & $50 \%$ & & $50 \%$ & & 1.2 & & [9] \\
\hline $\begin{array}{l}\text { Bifidobacterium } \\
\text { bifidium }\end{array}$ & $\mathrm{c} / \mathrm{LA}$ & $100 \%$ & & & & 1.0 & & [9] \\
\hline $\begin{array}{l}\text { Bifidobacterium } \\
\text { breve }\end{array}$ & $\mathrm{c} / \mathrm{LA}$ & $91 \%$ & $9 \%$ & & & 398 & $65 \%$ & [9] \\
\hline $\begin{array}{l}\text { Bifidobacterium } \\
\text { dentium }\end{array}$ & $\mathrm{c} / \mathrm{LA}$ & $78 \%$ & $21 \%$ & $1 \%$ & & 160 & & [9] \\
\hline $\begin{array}{l}\text { Bifidobacterium } \\
\text { infantis }\end{array}$ & $\mathrm{c} / \mathrm{LA}$ & $74 \%$ & $19 \%$ & $7 \%$ & & 24.6 & & [9] \\
\hline $\begin{array}{l}\text { Bifidobacterium } \\
\text { lactis }\end{array}$ & $\mathrm{c} / \mathrm{LA}$ & $90 \%$ & $8 \%$ & $2 \%$ & & 170 & & [9] \\
\hline $\begin{array}{l}\text { Bifidobacterium } \\
\text { pseudocatenulatum }\end{array}$ & $\mathrm{c} / \mathrm{LA}$ & $72 \%$ & $19 \%$ & $9 \%$ & & 23.3 & & [9] \\
\hline $\begin{array}{l}\text { Bifidobacterium } \\
\text { breve }\end{array}$ & $\mathrm{c} / \mathrm{LA}$ & $96 \%$ & & & & 160 & $78 \%$ & [58] \\
\hline $\begin{array}{l}\text { Bifidobacterium } \\
\text { pseudocatenulatum }\end{array}$ & $\mathrm{c} / \mathrm{LA}$ & $93 \%$ & & & & 135 & $69 \%$ & [58] \\
\hline $\begin{array}{l}\text { Butyrovibrio } \\
\text { fibrisolvens }\end{array}$ & $\mathrm{r} / \mathrm{LA}$ & $95 \%$ & & & & 220 & & [32] \\
\hline $\begin{array}{l}\text { Lactobacillus } \\
\text { acidophilus }\end{array}$ & $\mathrm{c} / \mathrm{LA}$ & $85 \%$ & $5 \%$ & $10 \%$ & & 131 & & {$[1]$} \\
\hline Lactobacillus casei & $\mathrm{c} / \mathrm{LA}$ & $85 \%$ & $3 \%$ & $12 \%$ & & 111 & & {$[1]$} \\
\hline Lactobacillus reuteri & $\mathrm{r} / \mathrm{LA}$ & $59 \%$ & & $41 \%$ & & 300 & & [39] \\
\hline Megaspaera elsdenii & $\mathrm{c} / \mathrm{LA}$ & $15 \%$ & & $85 \%$ & & $7 \mathrm{c}$ & & [35] \\
\hline $\begin{array}{l}\text { Lactococcus lactis } \\
\text { l-01 }\end{array}$ & $\mathrm{c} / \mathrm{SF}$ & & & & & $11^{\mathrm{d}}$ & & [34] \\
\hline $\begin{array}{l}\text { Propionibacterium } \\
\text { freudenreichii }\end{array}$ & $\mathrm{c} / \mathrm{LA}$ & $93 \%$ & & & & 265 & $87 \%$ & [30] \\
\hline $\begin{array}{l}\text { Lactobacillus } \\
\text { acidophilus }\end{array}$ & $\mathrm{r} / \mathrm{LA}$ & $67 \%$ & $33 \%$ & & & 4900 & & [56] \\
\hline $\begin{array}{l}\text { Lactobacillus } \\
\text { plantarum }\end{array}$ & $\mathrm{r} / \mathrm{LA}$ & $38 \%$ & $62 \%$ & & & 40000 & & [36] \\
\hline $\begin{array}{l}\text { Lactobacillus } \\
\text { plantarum }\end{array}$ & $\mathrm{r} / \mathrm{RA}$ & $21 \%$ & $79 \%$ & & & 2400 & & [2] \\
\hline $\begin{array}{l}\text { Lactobacillus } \\
\text { plantarum }\end{array}$ & $\mathrm{r} / \mathrm{CO}^{\mathrm{e}}$ & $26 \%$ & $74 \%$ & & & 2700 & & [3] \\
\hline $\begin{array}{l}\text { Bifidobacterium } \\
\text { breve }\end{array}$ & $\mathrm{c} / \mathrm{LA}$ & & & & & & $29 \% \mathrm{f}$ & [70] \\
\hline
\end{tabular}


Table I. Continued.

\begin{tabular}{|c|c|c|c|c|c|c|c|c|}
\hline Strain & $\begin{array}{l}\text { Reaction } \\
\text { method }^{\mathrm{a}} \\
\text { /substrate }\end{array}$ & & CLA i & isomers & & $\begin{array}{l}\text { Productivity } \\
\left(\mathrm{mg} \cdot \mathrm{L}^{-1}\right)\end{array}$ & $\begin{array}{c}\text { Conversion } \\
\text { of LA into CLA }\end{array}$ & Ref. \\
\hline & & c9, t11 & $\mathrm{t} 9, \mathrm{t} 11$ & $\mathrm{t} 10, \mathrm{c} 12$ & Others & & & \\
\hline $\begin{array}{l}\text { Propionibacterium } \\
\text { freudenreichii } \text { ssp. } \\
\text { shermanii } 51\end{array}$ & $\mathrm{c}^{\mathrm{h} / \mathrm{hSO}}$ & $85 \%$ & & $15 \%$ & & $1.65^{\mathrm{d}}$ & & [83] \\
\hline Lb. acidophilus $74-2$ & $\mathrm{c}^{\mathrm{h} / \mathrm{hSO}}$ & $48 \%$ & & $52 \%$ & & $0.94^{\mathrm{d}}$ & & [83] \\
\hline Yoghurt cultureg & $\mathrm{ch}^{\mathrm{h} / \mathrm{hSO}}$ & $79 \%$ & & $21 \%$ & & $0.90^{\mathrm{d}}$ & & [83] \\
\hline $\begin{array}{l}\text { Lactobacillus } \\
\text { rhamnosus }\end{array}$ & $\mathrm{c}^{\mathrm{i} / \mathrm{hSO}}$ & $58 \%$ & & $42 \%$ & & $1.68^{\mathrm{d}}$ & & [84] \\
\hline $\begin{array}{l}\text { Bifidobacterium } \\
\text { breve }\end{array}$ & $\mathrm{c} / \mathrm{LA}$ & & & & & 350 & $56.5 \%$ & [78] \\
\hline $\begin{array}{l}\text { Lactobacillus } \\
\text { delbrueckii ssp. } \\
\text { bulgaricus }\end{array}$ & $\mathrm{r} / \mathrm{LA}^{\mathrm{j}}$ & $56 \%$ & $26 \%$ & $2 \%$ & $16 \%$ & 208 & & [48] \\
\hline $\begin{array}{l}\text { Lactobacillus } \\
\text { delbrueckii ssp. } \\
\text { bulgaricus }\end{array}$ & $\mathrm{r} / \mathrm{LA}$ & $15 \%$ & $8 \%$ & $27 \%$ & $50 \%$ & 41.8 & & [45] \\
\hline $\begin{array}{l}\text { Lactobacillus } \\
\text { delbrueckii ssp. } \\
\text { bulgaricus }\end{array}$ & e/LA & $36 \%$ & $1 \%$ & $11 \%$ & $52 \%$ & 1.7 & & [45] \\
\hline
\end{tabular}

a c: cultivation; r: resting cell reaction; e: enzyme extract. ${ }^{\mathrm{b}}$ LA: linoleic acid; RA: ricinoleic acid; $\mathrm{CO}$ : castor oil; SF: sunflower oil; hSO: hydrolysed soy oil. ${ }^{\mathrm{c}} \mu \mathrm{g} \cdot \mathrm{mg}^{-1}$ protein. ${ }^{\mathrm{d}} \mathrm{mg} \cdot \mathrm{g}^{-1}$ fat. ${ }^{\mathrm{e}}$ Lipase added. $\mathrm{f}$ cis-9, trans-11 isomer. $\mathrm{g}$ Lb. delbrueckii ssp. bulgaricus and $S$. salivarius $\mathrm{ssp}$. thermophilus (1:1). ${ }^{\mathrm{h}}$ Milk model system. ${ }^{i}$ Milk model system and coculture with traditional yoghurt culture (Lb. delbrueckii ssp. bulgaricus and $S$. salivarius ssp. thermophilus). j Immobilised cells.

convert linoleic acid into CLA in a L-cysteine-enriched MRS media. The most efficient producers of CLA belonged to the species $B$. breve, of which two different strains converted 29 and $27 \%$ of the $0.5 \mathrm{mg} \cdot \mathrm{mL}^{-1}$ free linoleic acid into cis-9, trans-11 CLA per $\mu \mathrm{g}$ of dry cells. A strain of $B$. bifidum converted $18 \%$ per $\mu \mathrm{g}$ of dry cells. Song et al. [78] examined the conversion of linoleic acid into CLA and the adaptation of $B$. breve KCTC 3461 to linoleic acid. For linoleic acid-adapted $B$. breve the maximum concentration of CLA obtained in a L-cysteine-enriched MRS media containing $1 \mathrm{mg} \cdot \mathrm{mL}^{-1}$ linoleic acid was $300-350 \mu \mathrm{g} \cdot \mathrm{mL}^{-1}$. In a $2.5-\mathrm{L}$ stirred tank bioreactor the conversion rate reached $56.5 \%$ and the productivity 35.4 $\mu \mathrm{g} \cdot \mathrm{mL}^{-1} \cdot \mathrm{h}^{-1}$. CLA production capability improved with linoleic acid adaptation approximately 6.6 and 9.8 times.

\subsection{Lactic acid bacteria (lactobacilli, lactococci and streptococci)}

Ross et al. [71], Sieber et al. [77] and other authors report in their reviews that in addition to rumen bacteria, a number of other CLA-producing strains have been identified, including certain strains of bifidobacteria, probionibacteria, lactobacilli, lactococci, streptococci and other bacteria. Often free linoleic acid and sometimes sunflower oil [34] or other oils are added as a substrate. Kim and Liu [34] report that Lactococcus lactis l-01 showed the highest CLA-producing ability out of thirteen lactic 
acid bacteria screened. The highest CLA level was $11 \mathrm{mg} \cdot \mathrm{g}^{-1}$ fat (Tab. I). Further details of the study are mentioned in Section 5 (about yoghurt). Lin et al. [46] used an enzyme extract containing linoleic acid isomerase of Lactobacillus acidophilus and Propionibacterium freudenreichii ssp. shermanii. CLA formation was observed. Enzyme extract of $L b$. acidophilus gave more CLA and the amount reached $1700 \mu \mathrm{g}$ out of $50 \mathrm{mg}$ linoleic acid with $20 \mathrm{mg}$ enzyme extract. Trans-10, cis-12; cis-11, trans- 13 and cis- 9 , trans- 11 were the 3 major CLA isomers produced. Alonso et al. [1] tested four different cultures ( $L b$. acidophilus $L 1$ and $O 16$ and $L b$. casei E5 and $E 10)$ for the ability to convert free linoleic acid into CLA. Up to $131 \mu \mathrm{g} \mathrm{CLA} \cdot \mathrm{mL}^{-1}$ were found in MRS broth and up to $116 \mu \mathrm{g} \cdot \mathrm{mL}^{-1}$ in skimmed milk, both supplemented with an optimal linoleic acid concentration of $0.02 \%$. Lin et al. [47] tested crude enzyme extract from Lactobacillus acidophilus (CCRC 14079) for the production of CLA. Linoleic acid was used as a substrate. With $50 \mathrm{mg}$ enzyme extract and $75 \mathrm{mg}$ of linoleic acid, a level of $439 \mu \mathrm{g}$ CLA was reached in comparison with $116 \mu \mathrm{g}$ without enzyme extract. Fourteen \% of the formed CLA were of the isomer C18:2 cis-9, trans-11. Ando et al. [3] investigated the conditions for CLA production from enzyme-hydrolysed castor oil using washed cells of Lactobacillus plantarum JCM 1551, a strain which was previously selected as a potent CLA producer [2]. As the reaction media, using washed cells of Lb. plantarum JCM 1551 previously cultivated in MRS medium, $0.5 \mathrm{~mol} \cdot \mathrm{L}^{-1}$ sodium buffer (pH 6.0) at $37^{\circ} \mathrm{C}$ was used. The detergent Lubrol PX enhanced CLA production. With $5.0 \mathrm{mg} \cdot \mathrm{mL}^{-1}$ castor oil, $100 \mathrm{U} \cdot \mathrm{mL}^{-1}$ lipase M Amano 10 and $12 \%$ (w/v) washed cells, $2.7 \mathrm{mg} \cdot \mathrm{mL}^{-1}$ CLA was formed in $99 \mathrm{~h}$. The productivity was $0.044 \mathrm{mg} \cdot \mathrm{mL}^{-1} \cdot \mathrm{h}^{-1}$. The isomers were cis9, trans-11 (26\%) and trans-9, trans-11 (74\%). Coakley et al. [9] assessed strains of lactobacillus, lactococcus, pediococcus and bifidobacterium from different bacteria collections for their ability to produce CLA from free linoleic acid. Nine strains of bifidobacteria produced the cis-9, trans- 11
CLA isomer from free linoleic acid. Lactobacilli, lactococci and pediococci did not produce detectable CLA (see Sect. 4.2 on bifidobacteria).

With enzyme extract of Lb. acidophilus and linoleic acid addition, Lin et al. [47] observed high levels of CLA production (305 $\mu \mathrm{g}$ with $50 \mathrm{mg}$ LA and $439 \mu \mathrm{g}$ with $75 \mu \mathrm{g}$ LA). This shows the feasibility of CLA production through the enzyme method. With the enzyme reaction $14 \%$ of CLA were cis-9, trans-11-CLA, less than those reported in milk in studies with diet supplements. Lin [45] used washed cells and enzyme extract of a $L b$. delbrueckii ssp. bulgaricus strain to produce CLA. With the addition of linoleic acid the amount of CLA produced was significantly higher than without the addition of linoleic acid $(209 \mu \mathrm{g}$ in comparison with $27.0 \mu \mathrm{g}$ ). The main CLA isomers were trans-10, cis-12; trans10, trans-12 and cis-9, trans-11. Enzyme extract from the culture was capable of converting oleic and linoleic acid into CLA due to the possible presence of desaturase activity in the enzyme extract. However, the yields of CLA produced by the enzyme extract were much lower than those produced by the washed cells ( 8.5 vs. $209 \mu \mathrm{g})$. Ogawa et al. [57] observed that many strains were able to produce CLA from linoleic acid as washed cells under the following conditions: (a) they were obtained by cultivation in medium containing a small amount of linoleic acid; (b) the production of CLA by washed cells was clearly observed under microaerobic conditions; and (c) linoleic acid should be pretreated with a detergent or albumin so that it is well dispersed in the reaction mixture. High concentrations of up to $40 \mathrm{~g} \cdot \mathrm{L}^{-1}$ broth $\left(40000 \mathrm{mg} \cdot \mathrm{L}^{-1}\right)$ were reached (Tabs. I and II).

The CLA-producing reaction was found to consist of two successive reactions: the hydration of linoleic acid into 10-hydroxy12-octadecenoic acid and dehydrating isomerisation of the hydroxy fatty acid into CLA. Castor oil, which is rich in ricinoleic acid (12-hydroxy-cis-9-octadecenoic acid), was found to act as a substrate for CLA production by lactic acid bacteria with the aid of lipase. 
Table II. Potential strains for CLA production from linoleic acid [57].

\begin{tabular}{|c|c|c|c|c|}
\hline \multirow[t]{2}{*}{ Strain } & \multirow[t]{2}{*}{ Origin } & \multicolumn{3}{|c|}{ CLA (mg $\cdot \mathrm{L}^{-1}$ reaction mixture) } \\
\hline & & $\begin{array}{l}\text { cis-9, } \\
\text { trans-11 }\end{array}$ & $\begin{array}{l}\text { trans- } 9 \\
\text { trans-11 }\end{array}$ & $\begin{array}{l}\text { Total } \\
\text { CLA }\end{array}$ \\
\hline Enterococcus faecium & AKU 1021 & 40 & 60 & 100 \\
\hline Pediococcus acidilactici & AKU 1059 & 1000 & 400 & 1400 \\
\hline Propionibacterium shermanii & AKU 1254 & 90 & 20 & 110 \\
\hline Lactobacillus acidophilus & AKU 1137 & 850 & 650 & 1500 \\
\hline Lactobacillus acidophilus & IAM 10074 & 180 & 420 & 600 \\
\hline Lactobacillus acidophilus & AKU 1122 & 20 & 100 & 120 \\
\hline Lactobacillus brevis & IAM 1082 & 230 & 320 & 550 \\
\hline Lactobacillus paracase $i$ ssp. paracase $i$ & IFO 12004 & 50 & 150 & 200 \\
\hline Lactobacillus paracase $i$ ssp. paracase $i$ & JCM 1109 & 20 & 50 & 70 \\
\hline Lactobacillus paracasei ssp. paracasei & AKU 1142 & 40 & 30 & 70 \\
\hline Lactobacillus paracase i ssp. paracasei & IFO 3533 & 50 & 40 & 90 \\
\hline Lactobacillus pentosus & AKU 1148 & 50 & 30 & 80 \\
\hline Lactobacillus pentosus & IFO 12011 & 100 & 30 & 130 \\
\hline Lactobacillus plantarum & AKU 1138 & 100 & 350 & 450 \\
\hline Lactobacillus plantarum & AKU 1009a & 250 & 3160 & 3410 \\
\hline Lactobacillus plantarum & JCM 8341 & 40 & 150 & 190 \\
\hline Lactobacillus plantarum & JCM 1551 & 100 & 1920 & 2020 \\
\hline Lactobacillus rhamnosus & AKU 1124 & 690 & 720 & 1410 \\
\hline
\end{tabular}

\subsection{Immobilised lactic acid bacteria}

Lin et al. [48] produced CLA by washed cells of Lb. delbrueckii ssp. bulgaricus and Lb. acidophilus immobilised with chitosan and polyacrylamide. The immobilised cells were mixed with linoleic acid $(1.9 \%(\mathrm{v} / \mathrm{v}))$ and the highest CLA level reached was $2211 \mu \mathrm{g}\left(208 \mathrm{mg} \cdot \mathrm{L}^{-1}\right)$ with cells of Lb. delbrueckii ssp. bulgaricus immobilised with polyacrylamide. The results demonstrated a potential for enhancing CLA production through immobilisation.

\section{INFLUENCE OF CULTURES IN YOGHURT AND FERMENTED MILK}

Kim and Liu [34] screened thirteen lactic acid bacteria for CLA production ability in milk. Sunflower oil, containing $70 \%$ linoleic acid, was added as a substrate. Ten strains increased CLA formation in whole milk. Lactococcus lactis l-01 showed the highest CLA-producing ability. The optimal concentration of sunflower oil for CLA production was $0.1 \mathrm{~g} \cdot \mathrm{L}^{-1}$. The $\mathrm{pH}$, which was substantially lowered by lactic acid fermentation, stopped CLA production by the cells eventually. CLA concentration was $4.3 \mathrm{mg} \cdot \mathrm{g}^{-1}$ fat before fermentation. With the addition of $6 \%$ dry powder the CLA level increased up to $6.6 \mathrm{mg} \cdot \mathrm{g}^{-1}$ fat. Lin [44] produced non-fat set yoghurt with mixed cultures of Lb. acidophilus (CCRC14079) and yoghurt bacteria $L b$. delbrueckii ssp. bulgaricus and Streptococcus thermophilus with the addition of $0.1 \%$ linoleic acid. He found a significant increase in the CLA C18:2 cis9, trans-11 content $\left(2.95 \mu \mathrm{g} \cdot \mathrm{g}^{-1}\right.$ yoghurt compared with $1.10 \mu \mathrm{g} \cdot \mathrm{g}-1$ with standard yoghurt culture without any additive) without decreasing product acceptability, and therefore this mixed culture is suggested for the production of CLA-rich 
non-fat set yoghurt. Similarly, Xu et al. [84] found the highest content of CLA in fermented milk using the probiotic bacteria Lb. rhamnosus in coculture with a traditional yoghurt culture. As the lipid source, hydrolysed soy oil was added. CLA 18:2 cis-9, trans-11 content reached $0.97 \mathrm{mg} \cdot \mathrm{g}^{-1}$ lipid after 14 days of storage and was significantly higher than the $0.57 \mathrm{mg} \cdot \mathrm{g}^{-1}$ lipid with the standard yoghurt culture. Acidity, texture and flavour were similar to the fermented milk produced with yoghurt culture. Xu et al. [84] also evaluated the CLA-producing strains Propionibacterium freudenreichii ssp. shermanii 56, $P$. freudenreichii ssp. shermanii 51, and $P$. freudenreichii ssp. freudenreichii 23, previously selected in a model system. These strains also produced more CLA in coculture with standard yoghurt bacteria than as a single culture. Used as an adjunct culture, propionibacteria did not change the flavour profile or texture of the fermented milk but titrable acidity was significantly lower compared with fermentation with yoghurt culture alone.

\section{INFLUENCES OF CULTURES IN CHEESE}

Gnädig et al. [22] investigated the effect of different strains of Propionibacterium freudenreichii, either with low or high lipolytic activity, in comparison with cheese manufactured without propionibacteria. No changes in the CLA content or CLA isomer composition were observed. Das et al. [15] investigated the effect of yeast and bacterial adjuncts on the CLA content of washedcurd, dry-salted cheese. Three strains of $P$. freudenreichii ssp. shermanii converting free linoleic acid into CLA in laboratory media were used as adjunct strains, together with lipase-producing strains of Geotrichum candidum and Yarrowia lipolytica. Lb. fermentum was included to produce ethanol from lactose, a potential substrate for ethyl ester synthesis, while $L b$. rhamnosus was used to control the nonstarter lactic acid bacteria. In the culture media for $G$. candidum and $Y$. lipolytica, $1 \%(\mathrm{w} / \mathrm{v})$ linoleic acid-rich safflower oil was added. Linoleic acid-rich safflower oil was added to the cheese curd before pressing as well. Free linoleic acid was formed, but no conversion of linoleic acid into CLA was found, either during manufacturing or during 4 months of ripening. The lower $\mathrm{pH}$, lower water activity and the possible difficulty of contact between free linoleic acid and the propionibacteria are discussed as possible factors inhibiting the activity of the isomerase and the conversion into CLA. The presence of the other free fatty acids may also have affected the activity of the isomerase enzyme.

\section{DIFFERENT ENRICHMENT PROCEDURES}

\subsection{Influence of fractionation on CLA}

O'Shea et al. [55] investigated the effect of dry fractionation of bovine milk fat on CLA content in the resulting fractions. Anhydrous milk fat was fractionated into hard and soft fractions using controlled cooling and agitation. Pre-melted milk fat was cooled from $60{ }^{\circ} \mathrm{C}$ to the initial fractionation temperature $\left(33^{\circ} \mathrm{C}\right)$. Programmed cooling $\left(0.58,0.74,1.17\right.$ and $\left.2.8^{\circ} \mathrm{C} \cdot \mathrm{h}^{-1}\right)$ was then initiated until the final fractionation temperature $\left(19,15\right.$ and $\left.10^{\circ} \mathrm{C}\right)$ was reached. Agitation was initiated immediately and continued for $2 \mathrm{~h}$ at the final fractionation temperature. The fraction containing the crystallised fat was then separated from the soft fraction by centrifugation at $2500 \times g$ for $5 \mathrm{~min}$ at the final fractionation temperature. An increase in the CLA content from 1.36 to $2.22 \mathrm{~g} \cdot 100 \mathrm{~g}^{-1}$ FAME $(63.2 \%)$ was found in the soft fraction in comparison with the parent fat. Polyunsaturated fatty acids and vaccenic acid were also enriched compared with the parent fat. The optimum procedure was to cool at a slow rate of $0.58^{\circ} \mathrm{C} \cdot \mathrm{h}^{-1}$ in the temperature range of $33{ }^{\circ} \mathrm{C}$ to a low final temperature of $10{ }^{\circ} \mathrm{C}$. The yield of the soft fraction was $30 \%$ (w/w). Refractionation of the soft fraction using the same fractionation conditions did not improve the result but reduced the CLA 
content by $10 \%$ to $2.01 \mathrm{~g} \cdot 100 \mathrm{~g}^{-1}$ FAME. Agitation had a negative impact on the CLA content of the soft fraction. Our own investigations with dry fractionation showed lower increases in CLA content: $16 \%$ starting from CLA-rich highland butter (21.6 mg CLA.g-1 fat before fractionation), and $32 \%$ with butter from integrated farming (7.6 mg CLA.g ${ }^{-1}$ fat before fractionation). The yield of the CLArich fraction was $44 \%$ for highland butter [67].

\subsection{Influence of supercritical carbon dioxide extraction on CLA}

With a fractionation process using a continuous supercritical carbon dioxide system, Romero et al. [69] were able to increase the concentration of CLA by $89 \%$ from anhydrous milk fat, which was separated into five fractions. The fraction with this increase was $8.8 \%(\mathrm{w} / \mathrm{w})$ of the original anhydrous milk fat amount. The increase in CLA content in this fraction followed the same trend as the long-chain (C14 to $\mathrm{C} 18)$ unsaturated fatty acidcontaining triacylglycerols. Since supercritical carbon dioxide fractionation primarily occurs on the basis of molecular weight and dielectric properties of fatty acids and glycerides, these findings could be well explained. As supercritical extraction processes are established for industrial food production, e.g. to produce decaffeinated tea, it seems possible and is suggested that such CLA-rich fractions could be used as a special ingredient in other products such as milk, yoghurt, cheese or ice cream and be marketed as a neutraceutical.

\subsection{Influence of urea crystallisation on CLA}

Kim and Liu [33] concentrated natural CLA from milk fat by urea complexation. Milk fat was hydrolysed to provide free fatty acids, followed by crystallisation with different ratios of urea. Long-chain unsaturated fatty acids, including CLA, were concentrated after crystallisation. CLA was elevated from $5 \mathrm{mg} \cdot \mathrm{g}^{-1}$ fat to $12.7 \mathrm{mg} \cdot \mathrm{g}^{-1}$ fat $(2.5$ times $)$. The $\mathrm{C} 18: 1 /$
C18:0 fatty acid ratio was increased from 2 to 51, and stearic acid (C18:0) was decreased seventeen-fold.

\subsection{Influence of microfiltration on CLA}

CLA-enriched milk by a fish meal diet has been shown to have a reduced average fat globule size compared with control milk $(1.8 \mu \mathrm{m}$ and $2.3 \mu \mathrm{m})$ [5]. The casein micelle diameter of CLA-enriched milk was also lower [5]. Michalski et al. [53] and Fauquant et al. [19] investigated the influence of separation of small and larger milk fat globules by microfiltration of standard milk on the composition of milk fat. It was possible by microfiltration to receive different fractions of milk fat with different milk fat globule sizes. Native milk fat globules of average diameters ranging from $2.3 \mu \mathrm{m}$ to $8.0 \mu \mathrm{m}$ were obtained in the different fractions. Small fat globule triglyceride cores (removed from the milk fat globule membrane) contained more medium-chain fatty acids and less stearic acid than large fat globule triglyceride cores. No significant differences were found in the milk fat globule membrane lipids. Relatively, small milk fat globules always contained more CLA than the large milk fat globules, though discrepancies among different milk samples were observed. The main CLA isomer was cis-9, trans-11, the content of which tended to increase when the native milk fat globule size decreased (from $82.2 \%$ to $87.3 \%$ of total CLA isomers). The relative variation of some isomers between small and large fat globules from the same milk varied depending on milk origin. The potential to increase CLA content by fat globule fractionation seems to be limited.

\section{SHELF-LIFE STABILITY AND SPECIAL EFFECTS OF PROCESSING}

Unsaturated fatty acids are chemically more reactive than saturated fatty acids. Hence, fats or oils containing relatively high levels of unsaturated fatty acids have 
a shorter shelf life [72]. Also, Fearon [20] suggests that oxidative stability may become a critical factor in the production of a more unsaturated milk fat. Avramis et al. [5] studied milk enriched in CLA by a fish meal-supplemented diet. No difference in terms of colour, flavour or flavour stability was observed between CLA-enriched pasteurised and UHT milk compared with the control milk. In particular, no oxidised flavour was observed. Jones et al. [31] confirm these findings. Lynch et al. [51] exposed pasteurised milk rich in CLA (4.74 $\mathrm{g} \cdot 100 \mathrm{~g}^{-1}$ fatty acids) to light. There was no effect of light exposure on fatty acid composition initially or over a 14-d storage period. Untrained panellists were unable to detect flavour differences initially or over storage time. Campbell et al. [8] analysed the impact of highly CLA-fortified pasteurised dairy beverages similar to milk. The fat content of the dairy beverage was $2 \%$ and the CLA content up to $81.9 \%$ of fatty acid methyl esters. No differences were found in hexanal or other common indicators of lipid oxidation between milk and the CLA-fortified dairy beverage during the 2 weeks of refrigerated storage. Antioxidant treatment with vitamin $\mathrm{E}$ or rosemary extract had no effect. Ryhänen et al. [73] manufactured cheese and butter out of CLA-enriched milk with a CLA content of $0.82-1.10 \mathrm{~g} \cdot 100 \mathrm{~g}^{-1}$ total fatty acids. In cheese and butter the CLA content was 0.9 to $1.1 \%$ of fatty acids. The butter exhibited good storage characteristics and had acceptable grading scores. During the 14 weeks of storage, the free fatty acid content of the butter varied from 0.2 to $0.5 \mathrm{meq} \cdot 100 \mathrm{~g}^{-1}$ fat, values that are below the $1.5 \mathrm{meq} \cdot 100 \mathrm{~g}^{-1}$ fat threshold indicative of lipolysis [17]. The butter produced from CLA-enriched milk was softer than the control butter. Jones et al. [31] also observed no significant sensory differences between butter from CLA-enriched milk and the control, except a faster melt rate for the experimental butter. Gonzalez et al. [23] confirmed this. The sensory scores of the cheese made by Ryhänen et al. [73] from CLA-enriched milk after 12 weeks of storage were higher than those of control cheese. The cheese was of softer texture as well. Avramis et al. [5], Jones et al. [31] and Herzallah et al. [27] observed a desirable or no significant influence of CLA-enriched milk on the flavour and texture of stored Cheddar, Caerphilly cheese or white brined cheese. Gonzalez et al. [23] investigated the quality and shelf-life stability of ice cream made out of milk containing higher levels of linoleic acid and CLA achieved by a diet supplemented by safflower oil. During storage of the experimental ice cream some higher peroxide values as an indicator for autoxidation were measured, but not systematically. They were even lower sometimes compared with control ice cream. As mentioned in Section 2, Bergamo et al. [6] showed that organic products with an increased level of CLA also have an increased level of the natural antioxidants $\alpha$-tocopherol and $\beta$-carotene. This helps to protect them from oxidation.

\section{RESULTS OF CLA ANALYSIS IN CREAM AND BUTTER}

During September and October 2005 twelve samples of cream and the corresponding butter made out of the cream from a dairy in Lucerne, Switzerland, were analysed by our group according to the methods outlined in Table III. Seven samples were from integrated farming, which is the standard farming system in Switzerland, and five from organically produced milk (Tab. IV).

There were significant differences in total CLA content between cream of organically produced milk and cream made out of milk from integrated farming. The organic cream had an average content of $1.54 \mathrm{~g} \cdot 100 \mathrm{~g}^{-1}$ fat in comparison with $1.35 \mathrm{~g} \cdot 100 \mathrm{~g}^{-1}$ fat of the cream from integrated farming ( $14 \%$ higher). The same was valid for the corresponding butter. Organic butter had $1.48 \mathrm{~g} \mathrm{CLA} \cdot 100 \mathrm{~g}^{-1}$ fat compared with $1.31 \mathrm{~g}$ CLA $100 \mathrm{~g}^{-1}$ of butter from integrated farming $(13 \%$ higher). The butter-making process had no significant influence on the CLA content, either of organic cream processed into butter or of cream from integrated farming processed into butter. 
Table III. Analysis of fatty acid composition in organic and standard cream and butter.

\begin{tabular}{ccc}
\hline Step & Description of method & References \\
\hline 1 & Dissolution of milk fat in hexane & {$[10]$} \\
2 & Transesterification of triglycerides into corresponding FAME & {$[10]$} \\
$3 \mathrm{a}$ & $\begin{array}{c}\text { Analysis of FAME by GC (gas chromatography); results as } \\
\text { g fatty acids per 100 g fat (not as esters) }\end{array}$ & {$[10]$} \\
$3 \mathrm{~b}$ & $\begin{array}{c}\text { Analysis of CLA by Ag }{ }^{+} \text {-HPLC (high-performance liquid } \\
\text { chromatography); results in g per 100 g fat }\end{array}$ & {$[37,68]$} \\
\hline
\end{tabular}

Table IV. Total CLA content of cream and corresponding butter made of the cream. The values are from a dairy in Lucerne, Switzerland. Seven samples were from milk produced according to integrated farming guidelines and five from organically produced milk.

\begin{tabular}{lccccc}
\hline No. & Origin & $\begin{array}{c}\text { Date of } \\
\text { production }\end{array}$ & $\begin{array}{c}\text { CLA cream } \\
\left(\mathrm{g} \cdot 100 \mathrm{~g}^{-1} \text { fat }\right)\end{array}$ & $\begin{array}{c}\text { CLA butter } \\
\left(\mathrm{g} \cdot 100 \mathrm{~g}^{-1} \text { fat }\right)\end{array}$ & $\begin{array}{c}\text { Difference } \\
\text { butter-cream } \\
\left(\mathrm{g} \cdot 100 \mathrm{~g}^{-1} \text { fat }\right)\end{array}$ \\
\hline 1 & $\mathrm{i}$ & 28.09 .05 & 1.31 & 1.29 & -0.02 \\
2 & $\mathrm{i}$ & 28.09 .05 & 1.30 & 1.31 & 0.01 \\
3 & $\mathrm{i}$ & 28.09 .05 & 1.30 & 1.28 & -0.02 \\
4 & organic & 30.09 .05 & 1.55 & 1.51 & -0.04 \\
5 & organic & 30.09 .05 & 1.56 & 1.57 & 0.01 \\
6 & organic & 30.09 .05 & 1.56 & 1.49 & -0.07 \\
7 & $\mathrm{i}$ & 10.10 .05 & 1.37 & 1.27 & -0.10 \\
8 & organic & 13.10 .05 & 1.51 & 1.44 & -0.07 \\
9 & $\mathrm{i}$ & 18.10 .05 & 1.32 & 1.29 & -0.03 \\
10 & $\mathrm{i}$ & 19.10 .05 & 1.42 & 1.36 & -0.06 \\
11 & $\mathrm{i}$ & 20.10 .05 & 1.45 & 1.38 & -0.07 \\
12 & organic & 20.10 .05 & 1.54 & 1.41 & -0.13 \\
\hline$\varnothing$ & $\mathrm{i}$ & & $1.35^{\mathrm{ax}}$ & $1.31^{\mathrm{cx}}$ & -0.04 \\
$\varnothing$ & organic & & 1.54 by & $1.48^{\mathrm{dy}}$ & -0.06 \\
\hline
\end{tabular}

i: Integrated farming.

$\mathrm{a}, \mathrm{b}$ and $\mathrm{c}, \mathrm{d}$ : Different letters within columns mean significant differences $(P<0.001)$.

$\mathrm{x}, \mathrm{y}$ : Different letters within rows mean significant differences $(P<0.05)$.

\section{CONCLUSIONS}

In yoghurt there is a certain potential to increase CLA content by adjunct cultures under the condition that free linoleic acid or an oil and suitable lipase is added. This potential seems to be limited. Adjunct cultures with a high ability to convert linoleic acid into CLA showed no conversion, even in cheeses with high lipolytic activity. A disadvantage of the starter culture approach is the necessary linoleic acid as an additive. Free linoleic acid and CLA may have a negative influence on the flavour of the fermented milk products, though no such influence was observed in the reviewed literature. The major CLA formed by bacterial conversion is often the cis-9, trans-11 
isomer but sometimes other isomers are higher in concentration, e.g. trans- 9 , trans- 11 . In cultivated form Bifidobacterium breve reached a comparably high concentration of $398 \mathrm{mg} \mathrm{CLA} \cdot \mathrm{L}^{-1}$ broth, of which $91 \%$ were of the C18:2 cis-9, trans- 11 isomer.

Specific procedures allow one to increase the content of CLA in a fraction but these increases are either limited, or the procedures are complex and with limited yield, or not adapted for low-input food processing.

Many studies have been carried out on the shelf-life stability of dairy products with increased levels of CLA. In all the studies no significant differences in oxidation or other flavour quality parameters could be found. Storage of dairy products does not affect the content of CLA in dairy products. The higher levels of the antioxidants $\alpha$-tocopherol and $\beta$-carotene in organic milk fat has positive implications on the stability of the organic milk fat.

The conclusion is that processing and storage of dairy products generally does not change the concentration of CLA in milk fat. There is a reasonable potential for production of CLA in culture media and especially as washed cells. Especially bifidobacteria, propionibacteria, $L b$. plantarum, Lb. rhamnosus and Lb. acidophilus show high potential. As a substrate, free linoleic acid or free ricinoleic acid is necessary. The amount of added free linoleic acid in the substrate has to be well controlled as the starter cultures are sensitive to it, and too high amounts reduce the conversion rate into CLA $[1,57,78]$. An adaptation procedure of the bacteria to linoleic acid increases the conversion rate and productivity by up to 9.8 times. To increase CLA in dairy products two possible ways seem promising: the increase in CLA content through the diet of the dairy cattle and the production of CLA in special culture medium and then addition of the CLA into the dairy products. This second possibility involves a concentration and isolation process of the CLA out of the broth into a concentrated form which could be used as an additive. Further studies are necessary in this field to know if an economically feasible process can be developed which results in healthy products with a good flavour.
Acknowledgements: The authors gratefully acknowledge financial support from the Commission of the European Communities, under Priority Area 5 (Food Quality and Safety) of the Sixth Framework Programme for Research, Technological Development and Demonstration within the Integrated Project QUALITYLOWINPUTFOOD, FP6-FOODCT-2003-506358 and co-funding by the State Secretariat for Education and Research (SER), formerly Swiss Federal Office for Education and Science (BBW). This article does not necessarily reflect the Commission's views and in no way anticipates the Commission's future policy in this area.

\section{REFERENCE}

[1] Alonso L., Cuesta E.P., Gilliland S.E., Production of free conjugated linoleic acid by Lactobacillus acidophilus and Lactobacillus casei of human intestinal origin, J. Dairy Sci. 86 (2003) 1941-1946.

[2] Ando A., Ogawa J., Kishino S., Shimizu S., CLA production from ricinoleic acid by lactic acid bacteria, J. Am. Oil Chem. Soc. 80 (2003) 889-894.

[3] Ando A., Ogawa J., Kishino S., Shimizu S., Conjugated linoleic acid production from castor oil by Lactobacillus plantarum JCM 1551, Enzyme Microb. Technol. 35 (2004) 40-45.

[4] Aneja R.P., Murthi T.N., Conjugated linoleic acid contents of Indian curds and ghee, Indian J. Dairy Sci. 43 (1990) 231-238.

[5] Avramis C.A., Wang H., McBride B.W., Wright T.C., Hill A.R., Physical and processing properties of milk, butter, and Cheddar cheese from cows fed supplemental fish meal, J. Dairy Sci. 86 (2003) 25682576.

[6] Bergamo P., Fedele E., Iannibelli L., Marzillo G., Fat-soluble vitamin contents and fatty acid composition in organic and conventional Italian dairy products, Food Chem. 82 (2003) 625-631.

[7] Boylston T.D., Beitz D.C., Conjugated linoleic acid and fatty acid composition of yoghurt produced from milk of cows fed soy oil and conjugated linoleic acid, J. Food Sci. 67 (2002) 1973-1978.

[8] Campbell W., Drake M.A., Larick D.K., The impact of fortification with conjugated linoleic acid (CLA) on the quality of fluid milk, J. Dairy Sci. 86 (2003) 43-51. 
[9] Coakley M., Ross R.P., Nordgren M., Fitzgerald G., Devery R., Stanton C., Conjugated linoleic acid biosynthesis by humanderived Bifidobacterium species, J. Applied Microbiol. 94 (2003) 138-145.

[10] Collomb M., Bühler T., Analyse de composition en acides gras de la graisse de lait, optimisation et validation d'une méthode générale à haute résolution, Trav. Chim. Alim. Hyg. 91 (2000) 306-332.

[11] Collomb M., Bütikofer U., Sieber R., Jeangros B., Bosset J.O., Composition of fatty acids in cow's milk fat produced in the lowlands, mountains and highlands of Switzerland using high-resolution gas chromatography, Int. Dairy J. 12 (2002) 649-659.

[12] Collomb M., Sieber R., Bütikofer U., CLA isomers in milk fat from cows fed diets with high levels of unsaturated fatty acids, Lipids 39 (2004) 355-364.

[13] Collomb M.A., Schmid A., Sieber R., Wechsler D., Ryhänen E.L., Conjugated linoleic acids in milk fat: Variation and physiological effects, Int. Dairy J. 16 (2006) 1347-1361.

[14] Couvreur S., Hurtaud C., Lopez C., Delaby L., Peyraud J.L., The linear relationship between the proportion of fresh grass in the cow diet, milk fatty acid composition, and butter properties, J. Dairy Sci. 89 (2006) 1956-1969.

[15] Das S., Holland R., Crow V.L., Bennett R.J., Manderson G.J., Effect of yeast and bacterial adjuncts on the CLA content and flavour of a washed-curd, dry salted cheese, Int. Dairy J. 15 (2005) 807-815.

[16] Dave R.I., Ramaswamy N., Baer R.J., Changes in fatty acid composition during yoghurt processing and their effects on yoghurt and probiotic bacteria in milk procured from cows fed different diets, Aust. J. Dairy Technol. 57 (2002) 197-202.

[17] Deeth H.C., Fitz-Gerald C.H., Lipolytic enzymes and hydrolytic rancidity in milk and milk products, in: Fox P.F. (Ed.), Development in dairy chemistry, Vol. 2, Applied Science Publishers, London, UK, 1983, pp. 195-239.

[18] Ellis K.A., Innocent G., Grove-White D., Cripps P., McLean W.G., Howard C.V., Mihm M., Comparing the fatty acid composition of organic and conventional milk, J. Dairy Sci. 89 (2006) 1938-1950.

[19] Fauquant C., Briard V., Leconte N., Michalski M.-C., Differently sized native milk fat globules separated by microfiltration: fatty acid composition of the milk fat globule membrane and triglyceride core, Eur. J. Lipid Sci. Technol. 107 (2005) 80-86.

[20] Fearon A.M., Optimising milkfat composition and processing properties, Aust. J. Dairy Technol. 56 (2001) 104-108.

[21] Garcia-Lopez S., Echeverria E., Tsui I., Balch B., Changes in the content of conjugated linoleic acid (CLA) in processed cheese during processing, Food Res. Int. 27 (1994) 61-64.

[22] Gnädig S., Chamba J.F., Perreard E., Chappaz S., Chardigny J.M., Rickert R., Steinhart H., Sébédio J.L., Influence of manufacturing conditions on the conjugated linoleic acid content and the isomer composition in ripened French Emmental cheese, J. Dairy Res. 71 (2004) 367-371.

[23] Gonzalez S., Duncan S.E., O'Keefe S.F., Sumner S.S., Herbein J.H., Oxidation and textural characteristics of butter and ice cream with modified fatty acid profiles, J. Dairy Sci. 86 (2003) 70-77.

[24] Gürsoy O., Seckin A.K., Kinik Ö., Metin M. Conjugated linoleic acid (CLA) content of most popular Turkish hard and soft cheeses, Milchwissenschaft 58 (2003) 622-623.

[25] Ha Y.L., Grimm N.K., Pariza M.W., Anticarcinogens from fried ground beef: heataltered derivatives of linoleic acid, Carcinogenesis 8 (1987) 1881-1887.

[26] Ha Y.L., Grimm N.K., Pariza M.W., Newly recognized anticarcinogenic fatty acids: identification and quantification in natural and processed cheeses, J. Agric. Food Chem. 37 (1989) 75-81.

[27] Herzallah S.M., Humeid M.A., Al-Ismail K.M., Effect of heating and processing methods of milk and dairy products on conjugated linoleic acid and trans fatty acid isomer content, J. Dairy Sci. 88 (2005) 13011310.

[28] Jahreis G., Fritsche J., Steinhard H., Conjugated linoleic acid in milk fat: High variation depending on production system, Nutr. Res. 17 (1997) 1479-1484.

[29] Jiang J., Björck L., Fondén R., Conjugated linoleic acid in Swedish dairy products with special reference to the manufacture of hard cheese, Int. Dairy J. 7 (1997) 863-867.

[30] Jiang J., Björck L., Fondén R., Production of conjugated linoleic acid by dairy starter cultures, J. Applied Microbiol. 85 (1998) $95-102$. 
[31] Jones E.L., Shingfield K.J., Kohen C., Jones A.K., Lupoli B., Grandison A.S., Beever D.E., Williams C.M., Calder P.C., Yaqoob P., Chemical, physical, and sensory properties of dairy products enriched with conjugated linoleic acid, J. Dairy Sci. 88 (2005) 2923-2937.

[32] Kim Y.J., Partial inhibition of biohydrogenation of linoleic acid can increase the conjugated linoleic acid production of Butyrivibrio fibrisolvens A38, J. Agric. Food Chem. 51 (2003) 4258-4262.

[33] Kim Y.J., Liu R.H., Selective increase in conjugated linoleic acid in milk fat by crystallization, J. Food Sci. 64 (1999) 792-795.

[34] Kim Y.J., Liu R.H., Increase of conjugated linoleic acid content in milk by fermentation with lactic acid bacteria, J. Food Sci. 67 (2002) 1731-1838.

[35] Kim Y.J., Liu R.H., Rychlik J.L., Russell J.B., The enrichment of a ruminal bacterium (Megasphaera elsdenii YJ-4) that produces the trans- 10 , cis-12 isomer of conjugated linoleic acid, J. Applied Microbiol. 92 (2002) 976-982.

[36] Kishino S., Ogawa J., Omura Y., Matsumara K., Shimizu S., Conjugated linoleic acid production from linoleic acid by lactic acid bacteria, J. Am. Oil Chem. Soc. 79 (2002) 159-163.

[37] Kraft J., Collomb M., Möckel P., Sieber R., Jahreis G., Differences in CLA isomer distribution of cow's milk fat produced in the lowlands, mountains and highlands of Switzerland and botanical composition of the fodder, Lipids 38 (2003) 657-664.

[38] Ledoux M., Chardigny J.M., Darbois M., Soustre Y., Sebedio J.L., Laloux L., Fatty acid composition of French butters, with special emphasis on conjugated linoleic acid (CLA) isomers, J. Food Compos. Anal. 18 (2005) 409-425.

[39] Lee S.O., Kim C.S., Cho S.K., Choi H.J., Ji G.E., Oh D.K., Bioconversion of linoleic acid into conjugated linoleic acid during fermentation and by washed cells of Lactobacillus reuteri, Biotechnol. Lett. 25 (2003) 935-938.

[40] Leiber F., Kreuzer M., Nigg D., Wettstein H.R., Scheeder M.R.L., A study on the causes for the elevated n-3 fatty acids in cows' milk of alpine origin, Lipids 40 (2005) 191-202.

[41] Lin H., Boylston T.D., Chang M.J., Luedecke L.O., Shultz T.D., Survey of the conjugated linoleic acid contents of dairy products, J. Dairy Sci. 78 (1995) 2358-2365.
[42] Lin H., Boylston T.D., Luedecke L.O., Shultz T.D., Factors affecting the conjugated linoleic acid content of Cheddar cheese, J. Agric. Food Chem. 46 (1998) 801-807.

[43] Lin H., Boylston T.D., Luedecke L.O., Shultz T.D., Conjugated linoleic acid content of cheddar-type cheeses as affected by processing, J. Food Sci. 64 (1999) 874-878.

[44] Lin T.Y., Influence of lactic cultures, linoleic acid and fructo-oligosaccharides on conjugated linoleic acid concentration in non-fat set yogurt, Aust. J. Dairy Technol. 58 (2003) $11-14$.

[45] Lin T.Y., Conjugated linoleic acid production by cells and enzyme extract of Lactobacillus delbrueckii ssp bulgaricus with additions of different fatty acids, Food Chem. 94 (2006) 437-441.

[46] Lin T.Y., Lin C.W., Wang Y.J., Linoleic acid isomerase activity in enzyme extracts from Lactobacillus acidophilus and Propionibacterium freudenreichii ssp shermanii, J. Food Sci. 67 (2002) 1502-1505.

[47] Lin T.Y., Lin C.W., Wang Y.J., Production of conjugated linoleic acid by enzyme extract of Lactobacillus acidophilus CCRC 14079, Food Chem. 83 (2003) 27-31.

[48] Lin T.Y., Hung T.-H., Cheng T.S.J., Conjugated linoleic acid production by immobilized cells of Lactobacillus delbrueckii ssp. bulgaricus and Lactobacillus acidophilus, Food Chem. 92 (2005) 23-28.

[49] Luna P., Martin-Diana A.B., Alonso L., Fontecha J., de la Fuente M.A., Requena T., Juarez M., Effects of milk fat replacement by PUFA enriched fats on $\mathrm{n}-3$ fatty acids, conjugated dienes and volatile compounds of fermented milks, Eur. J. Lipid Sci. Technol. 106 (2004) 417-423.

[50] Luna P., de la Fuente M.A., Juarez M., Conjugated linoleic acid in processed cheeses during the manufacturing stages, J. Agric. Food Chem. 53 (2005) 2690-2695.

[51] Lynch J.M., Lock A.L., Dwyer D.A., Noorbakhsh R., Barbano D.M., Bauman D.E., Flavor and stability of pasteurized milk with elevated levels of conjugated linoleic acid and vaccenic acid, J. Dairy Sci. 88 (2005) 489-498.

[52] Michalski M.C., Januel C., Does homogenization affect the human health properties of cow's milk?, Trends Food Sci. Technol. 17 (2006) 423-437.

[53] Michalski M.-C., Briard V., Juaneda P., CLA profile in native fat globules of different 
sizes selected from raw milk, Int. Dairy J. 15 (2005) 1089-1094

[54] Nudda A., McGuire M.A., Battacone G., Pulina G., Seasonal variation in conjugated linoleic acid and vaccenic acid in milk fat of sheep and its transfer to cheese and Ricotta, J. Dairy Sci. 88 (2005) 1311-1319.

[55] O'Shea M., Devery R., Lawless F., Keogh K., Stanton C., Enrichment of the conjugated linoleic acid content of bovine milk fat by dry fractionation, Int. Dairy J. 10 (2000) 289-294.

[56] Ogawa J., Matsumura K., Kishino S., Omura Y., Shimizu S., Conjugated linoleic acid accumulation via 10-hydroxy-12 octadecaenoic acid during microaerobic transformation of linoleic acid by Lactobacillus acidophilus, Appl. Environ. Microbiol. 67 (2001) 1246-1252.

[57] Ogawa J., Kishino S., Ando A., Sugimoto S., Mihara K., Shimizu S., Production of conjugated fatty acids by lactic acid bacteria, $\mathrm{J}$. Biosci. Bioeng. 100 (2005) 355-364.

[58] Oh D.K., Hong G.H., Lee Y., Min S.G., Sin H.S., Cho S.K., Production of conjugated linoleic acid by isolated Bifidobacterium strains, World J. Microbiol. Biotechnol. 19 (2003) 907-912.

[59] Pariza M.W., Hargraves W.A., A beefderived mutagenesis modulator inhibits initiation of mouse epidermal tumors by 7,12dimethylbenz[a]anthracene, Carcinogenesis 6 (1985) 591-593.

[60] Pariza M.W., Park Y., Cook M.E., The biologically active isomers of conjugated linoleic acid - a review, Prog. Lipid Res. 40 (2001) 283-298.

[61] Parodi P.W., Cow's milk fat components as potential anticarcinogenic agents, J. Nutr. 127 (1997) 1055-1060.

[62] Parodi P.W., Conjugated linoleic acid: The early years, in: Yurawecz M.P., Mossoba M.M., Kramer J.K.G., Pariza M.W., Nelson G.J. (Eds.), Advances in Conjugated Linoleic Acid Research, Vol. 1, AOAC Press, Champaign, IL, USA, 1999, pp. 1-11.

[63] Prandini A., Geromin D., Conti F., Masoero F., Piva A., Piva G., Survey on the level of conjugated linoleic acid in dairy products, Ital. J. Food Sci. 13 (2001) 243-253.

[64] Precht D., Molkentin J., Vahlendieck M., Influence of the heating temperature on the fat composition of milk fat with emphasis on cis-/trans-isomerization, Nahrung 43 (1999) 25-33
[65] Rainio A., Vahvaselka M., Suomalainen T., Laakso S., Production of conjugated linoleic acid by Propionibacterium freudenreichii ssp. shermanii, Lait 82 (2002) 91-101.

[66] Rego O.A., Rosa H.J.D., Portugal P.V., Franco T., Vouzela C.M., Borba A.E.S., Bessa R.J.B., The effects of supplementation with sunflower and soybean oils on the fatty acid profile of milk fat from grazing dairy cows, Anim. Res. 54 (2005) 17-24.

[67] Rehberger B., Bütikofer U., Bisig W., Collomb M., Short communication: Influence of a dry fractionation of butter fat on the content of fatty acids including conjugated linoleic acids, Eur. Food Res. Technol., in press (DOI 10.1007/s00217-0060544-1).

[68] Rickert R., Steinhart H., Fritsche J., Sehat N., Yurawecz M.P., Mossoba M.M., Roach J.A.G., Eulitz K., Ku Y., Kramer J.K.G., Enhanced resolution of CLA isomers by tandem-column silver-ion high performance liquid chromatography, J. High Res. Chromatogr. 22 (1999) 144-148.

[69] Romero P., Rizvi S.S.H., Kelly M.L., Bauman D.E., Short communication: Concentration of conjugated linoleic acid from milk fat with a continuous supercritical fluid processing system, J. Dairy Sci. 83 (2000) 20-22.

[70] Rosberg-Cody E., Ross R.P., Hussey S., Ryan C.A., Murphy B.P., Fitzgerald G.F., Devery R., Stanton C., Mining the microbiota of the neonatal gastrointestinal tract for conjugated linoleic acid-producing bifidobacteria, Appl. Environ. Microbiol. 70 (2004) 4635-4641.

[71] Ross R.P., Stanton C., Hill C., Fitzgerald G.F., Coffey A., Novel cultures for cheese improvement, Trends Food Sci. Technol. 11 (2000) 96-104.

[72] Rossel J.B., Intermediate shelf life products as illustrated by fats and fatty foods, Food Sci. Technol. Today 3 (1989) 235-240.

[73] Ryhänen E.L., Tallavaara K., Griinari J.M., Jaakkola S., Mantere-Alhonen S., Shingfield K.J., Production of conjugated linoleic acid enriched milk and dairy products from cows receiving grass silage supplemented with a cereal-based concentrate containing rapeseed oil, Int. Dairy J. 15 (2005) 207-217.

[74] Shantha N.C., Decker E.A., Ustunol Z., Conjugated linoleic acid concentration in processed cheese, J. Am. Oil Chem. Soc. 69 (1992) 425-428.

[75] Shantha N.C., Ram L.N., O'Leary J., Hicks C.L., Decker E.A., Conjugated linoleic acid 
concentrations in dairy products as affected by processing and storage, J. Food Sci. 60 (1995) 695-697.

[76] Shingfield K.J., Reynolds C.K., Hervas G., Griinari J.M., Grandison A.S., Beever D.E., Examination of the persistency of milk fatty acid composition responses to fish oil and sunflower oil in the diet of dairy cows, J. Dairy Sci. 89 (2006) 714-732.

[77] Sieber R., Collomb M., Aeschlimann A., Jelen P., Eyer H., Impact of microbial cultures on conjugated linoleic acid in dairy products - a review, Int. Dairy J. 14 (2004) $1-15$.

[78] Song Y.S., Kang S.W., Oh D.K., Rho Y.T., Hong S.I., Kim S.W., Bioconversion of linoleic acid to conjugated linoleic acid by Bifidobacterium breve, Biotechnol. Bioprocess Eng. 10 (2005) 357-361.

[79] Steinhart C., Conjugated linoleic acid - the good news about animal fat, J. Chem. 73 (1996) 302-303.

[80] van Nieuwenhove C., Gonzalez S., PerezChaia A., Holgado A.P.D., Conjugated lino- leic acid in buffalo (Bubalus bubalis) milk from Argentina, Milchwissenschaft 59 (2004) 506-508.

[81] Wahle K.W.J., Heys S.D., Rotondo D., Conjugated linoleic acids: are they beneficial or detrimental to health?, Prog. Lipid Res. 43 (2004) 553-587.

[82] Werner S.A., Luedecke L.O., Shultz T.D., Determination of conjugated linoleic acid content and isomer distribution in three Cheddar-type cheeses: effects of cheese cultures, processing, and aging, J. Agric. Food Chem. 40 (1992) 1817-1821.

[83] Xu S., Boylston T.D., Glatz B.A., Effect of lipid source on probiotic bacteria and conjugated linoleic acid formation in milk model systems, J. Am. Oil Chem. Soc. 81 (2004) 589-595.

[84] Xu S., Boylston T.D., Glatz B.A., Conjugated linoleic acid content and organoleptic attributes of fermented milk products produced with probiotic bacteria, J. Agric. Food Chem. 53 (2005) 9064-9072. 